\title{
ANALISIS FAKTOR DIABETES MELITUS TERHADAP PASIEN PENYAKIT JANTUNG KORONER (PJK) DI RS TNI AU DR DODY SARJOTO MAKASSAR
}

\author{
Hasta Handayani Idrus* \\ *Bagian Mikrobiologi Fakultas Kedokteran Universitas Muslim Indonesia Makassar
}

\begin{abstract}
Abstrak
Latar Belakang : Survei kesehatan rumah tangga yang dilakukan secara berkala oleh Departemen Kesehatan Republik Indonesia menunjukkan bahwa penyakit kardiovaskuler memberikan kontribusi sebesar 19,8\% dari seluruh penyebab kematian pada tahun 2011 dan meningkat menjadi 24,4\% pada tahun 2011 (Goya 2011). Penyakit kardiovaskuler, termasuk PJK, merupakan salah satu gejala jangka panjang dari masa peralihan ini dan penyakit diabetes mellitus merupakan faktor pencetus progresifitas terjadinya PJK oleha karena itu peneliti sangat tertarik untuk meneliti hubungan faktor resiko penyakit diabetes mellitus terhadap angka kejadian pasien penyakit jantung koroner (PJK). Metode Penelitian : Penelitian ini termasuk penelitian Observational Analitik yaitu penelitian yang bertujuan menjelaskan hubungan antar variabel, yang dalam hal ini adalah variabel faktor risiko penyakit Diabetes melitus dan variabel penyakit jantung koroner (PJK). Rancangan penelitian yang digunakan adalah case-control, dimana kasus dan kontrol telah diketahui pada saat (awal) penelitian, kemudian ditelusuri secara retrospektif faktor risiko (paparan) yang berperan dalam kejadian PJK. Hasil Penelitian : Menunjukkan bahwa pada pasien PJK, sebagian besar responden memiliki DM sebesar 73,4\%, sedangkan responden yang tidak memiliki DM sebesar 26,6\%. Kelompok bukan PJK, persentase responden memiliki DM yaitu sebesar 41,7 \%, sedangkan yang tidak memiliki DM sebesar $58,3 \%$. Nilai $X^{2}$ hitung $(4,721)<X_{\text {tabel }}^{2}(3,841)$ atau nilai $p(0,03)<\alpha(0,05)$ berarti bahwa ada hubungan antara diabetes melitus dengan kejadian PJK. Kesimpulan : Hasil penelitian diperoleh ada hubungan yang bermakna antara diabetes melitus dengan kejadian PJK.
\end{abstract}

Kata Kunci : Penyakit Jantung koroner, Diabetes mellitus. 
PENDAHULUAN

Penyakit

menempati urutan pertama sebagai penyebab kematian di Indonesia saat ini. Survei kesehatan rumah tangga yang dilakukan secara berkala oleh Departemen Kesehatan Republik Indonesia menunjukkan bahwa penyakit kardiovaskuler memberikan kontribusi sebesar 19,8\% dari seluruh penyebab kematian pada tahun 2011 dan meningkat menjadi $24,4 \%$ pada tahun 2011 (Goya 2011).

Pria umur pertengahan dan wanita dengan diabetes mellitus (DM) memiliki risiko tinggi untuk menderita PJK, baik orang kulit hitam maupun kulit putih. Risiko relatif PJK untuk pasien dengan DM adalah 3,95 pada wanita dan 2,41 pada pria (Rose, 2012)

Indonesia mempunyai jumlah penduduk 217.131.000 jiwa pada tahun 2002, mengalami kehilangan tenaga untuk aktivitas harian karena ketidakmampuan bekerja sebanyak 14 orang per 1.000 penduduk pada tahun 2011 dan jumlah kematian sebanyak 220.372 orang selama tahun 2011 akibat penyakit jantung (Atika, 2012)

Penyakit kardiovaskuler, termasuk PJK, merupakan salah satu gejala jangka panjang dari masa peralihan ini dan penyakit diabetes mellitus merupakan faktor pencetus progresifitas terjadinya PJK oleha karena itu peneliti sangat tertarik untuk meneliti hubungan faktor resiko penyakit diabetes mellitus terhadap angka kejadian pasien penyakit jantung koroner (PJK).

\section{METODE PENELITIAN}

Penelitian ini termasuk penelitian Observational Analitik yaitu penelitian yang bertujuan menjelaskan hubungan antar variabel, yang dalam hal ini adalah variabel faktor risiko penyakit Diabetes melitus dan variabel penyakit jantung koroner (PJK). Rancangan penelitian yang digunakan adalah case-control, dimana kasus dan kontrol telah diketahui pada saat (awal) penelitian, kemudian ditelusuri secara retrospektif faktor risiko (paparan) yang berperan dalam kejadian PJK.

Penelitian Penelitian ini akan direncanakan pada pasien yang yang berobat di poli penyakit dalam RS TNI AU Dody Sarjoto Makassar. Waktu Penelitian Penelitian ini akan direncanakan pada bulan Juli - Agustus 2017. Populasi yang dimaksud dalam penelitian ini adalah seluruh pasien yang berobat di RS TNI AU Dody 
Sarjoto Makassar pada bulan Juli September 2017. Sampel yang digunakan dalam penelitian ini adalah semau pasien yang berkunjung di poli penyakit dalam RS TNI AU Dody terhadap responden dengan Sarjoto Makassar pada bulan Juli Agustus 2017.

menggunakan kuesioner dan wawancara langsung. Data Sekunder Data sekunder diperoleh dari rekam medis di RS TNI AU Dody Sarjoto

\section{Instrumen}

Instrumen yang dipakai dalam penelitian ini adalah daftar pertanyaan berupa kuesioner. Menggunakan alat pengukur tekanan darah dan kolesterol yang baik sesuai dengan standar. Pengumpulan Data .Data primer Data primer diperoleh melalui wawancara

\section{HASIL PENELITIAN}

Tabel 1. Distribusi responden berdasarkan karakteristik

\begin{tabular}{lccc}
\multicolumn{1}{c}{ Variabel } & n & $\%$ & Total \\
\hline Status PJK & & & \\
PJK & 64 & 84,2 & \\
Non PJK & 12 & 15,8 & 76 \\
Diabetes Melitus & & & \\
DM & 52 & 68,4 & \\
Tidak DM & 24 & 31,6 & 76 \\
\hline Sumber
\end{tabular}

Sumber : Data Primer

Tabel 1. di atas menunjukkan

distribusi responden berdasarkan variabel yang diteliti. Diperoleh jumlah penderita PJK sebesar 84,2\% dan non PJK sebesar 15,8\%.. Pada kelompok Diabetes Melitus diperoleh distribusi penderita DM sebesar 68,4\% sedangkan bukan DM sebesar $31,6 \%$.

\section{Tabel 2. Hubungan Diabetes} mellitus dan PJK

\begin{tabular}{|c|c|c|c|c|c|}
\hline \multirow{3}{*}{$\begin{array}{c}\text { Diabetes } \\
\text { Melitus }\end{array}$} & \multicolumn{4}{|c|}{ Status PJK } & \multirow{3}{*}{$\begin{array}{l}\mathbf{X}^{2} \\
(\mathbf{p})\end{array}$} \\
\hline & \multicolumn{2}{|c|}{ PJK } & \multicolumn{2}{|c|}{$\begin{array}{c}\text { Bukan } \\
\text { PJK }\end{array}$} & \\
\hline & n & $\%$ & $\mathbf{n}$ & $\%$ & \\
\hline DM & 47 & 73,4 & 5 & 41,7 & \\
\hline Tidak & 17 & 26,6 & 7 & 58,3 & \\
\hline DM & & & & & 4,721 \\
\hline Total & 64 & 100 & 12 & 100 & $(0,03)$ \\
\hline
\end{tabular}

Tabel 2. di atas menunjukkan bahwa pada pasien PJK, sebagian besar responden memiliki DM sebesar $73,4 \%$, sedangkan responden yang tidak memiliki DM sebesar 26,6\%. Kelompok bukan PJK, 
persentase responden memiliki DM yaitu sebesar 41,7 \%, sedangkan yang tidak memiliki DM sebesar $58,3 \%$. Nilai $\mathrm{X}^{2}$ hitung $(4,721)<\mathrm{X}_{\text {tabel }}^{2}$ $(3,841)$ atau nilai $\mathrm{p}(0,03)<\alpha(0,05)$ berarti bahwa ada hubungan antara diabetes melitus dengan kejadian PJK.

\section{PEMBAHASAN}

Hasil penelitian diperoleh ada hubungan yang bermakna antara diabetes melitus dengan kejadian PJK, hasil analisis menunjukkan $\mathrm{p}$ value $=0,03$. Hal tersebut sesuai dengan apa yang peneliti temukan dilapangan dimana responden yang mengalami penyakit jantung koroner dan diabetes melitus memiliki jumlah yang lebih besar dibandingkan dengan responden yang tidak diabetes melitus.

Hal tersebut di dukung oleh teori yang menyatakan bahwa diabetes melitus yakni kadar glukosa yang tinggi di dalam darah cenderung menaikkan kadar kolesterol dan trigliserida. Peningkatan risiko diabetes disebabkan kelainan lipid. Mekanisme belum jelas, akan tetapi terjadi peningkatan tipe IV hiperlipidemi dan hipertrigliserid, pembentukan platelet yang abnormal sehingga memicu terjadinya penyakit jantung koroner.

Hasil penelitian tersebut juga sesuai dengan teori Lewis, et all. (2011) yang menyatakan bahwa kejadian PJK meningkat lebih besar 2-4 kali lebih besar pada orang yang terkena DM, karena seseorang dengan penyakit DM cenderung lebih cepat mengalami degenerasi jaringan dan disfungsi endotel.

Hasil penelitian tersebut juga sejalan dengan penelitian yang dilakukan oleh Frimingham dimana satu dari dua orang penderita DM akan mengalami kerusakan pembuluh darah dan peningkatan risiko serangan jantung. Diabetes mellitus akan timbul proses penebalan membran basalis dari kapiler dan pembuluh darah arteri koronaria, sehingga terjadi penyempitan aliran darah ke jantung.

\section{KESIMPULAN}

Dari hasil penelitian didapatkan bahwa pada pasien PJK, sebagian besar responden memiliki DM sebesar $73,4 \%$ dan nilai $p(0,03)$ $<\alpha(0,05)$ berarti bahwa ada 
hubungan antara diabetes melitus dengan kejadian PJK.

\section{DAFTAR PUSTAKA}

1. Ades PA, Cardiac rehabilitation and secondary prevention of coronary heart disease, N Engl J Med 2011; 345: 892-902.

2. American Heart Association (AHA)-Scientific Position, Risk factors and coronary heart disease, AHA Scientific Position, November 24, 2012, 1-3.

3. Andreasson S, Allebeck $\mathrm{P}$, Romelsjo A, Alcohol and mortality among young man, BMJ, 2010;296: 1021-1025. (PubMed)

4. Anna Ulfa, Gejala awal dan deteksi dini penyakit jantung koroner, Artikel Ilmiah PdPERSI, Jakarta, 2012.

5. Anis, Waspada Ancaman penyakit tidak menular, Solusi Pencegahan dari Aspek Perilaku \& Lingkungan, PT Elex Media Komputindo, Jakarta, 2011, 53-65.

6. Atika Walujani M, Perlu program penanggulangan penyakit kardiovaskuler, Kompas Cyber Media - IPTEK, 4 Juni 2011.

7. Barbara C. Long, Medical and Surgical Nursing - A nursing process approach, The C.V Mosby Company St. Louis, USA, 2014.

8. Batalla A, Reguero JR, Hevia S, et al, Mild hypercholesterolemia and premature heart disease, $\mathrm{J}$ Am Call Cardiol, 2012;37:331

9. Beaglehole R, Jackson R, Alcohol, cardiovascular disease and all causes of death: a review of the epidemiological evidence, Drug Alcohol Rev. 2011;11: 275-290

10. Bisma Murti, Prinsip dan metode riset epidemilogi : populasi, sampel dan pemilihan subyek, Cetakan Pertama, Gajah Mada University Press, Yogyakarta, 2011: 72-81.

11. Boedhi Darmojo, R, KrisPranarka \& Sutrisno, B, Survei penyakit jantung pada orang usia lanjut, Dalam : Bunga Rampai Karangan Ilmiah, Buku II, Kardiovaskular, 2010, 168179.

12. Burch PRJ, Coronary disease : Risk factors, age, and time, Am Heart J, 2011; 97:415-419.

13. Christen WG, Anjani UA, Glyn $\mathrm{RJ}$, Hennekens $\mathrm{CH}$, Blood levels of homocysteine and increased risk of cardiovascular diseasecausal or causal, Arch Intern Med, 2013; 160: 422.

14. Daniel Hayes, M.D, Distress sudden exercise raise heart attack risk, American Heart Association, July 27, 2014, 1-4.

15. Departemen Kesehatan RI, Indonesia Sehat 2010 - visi baru, Misikebijakan dan strategi pembangunan kesehatan, Jakarta, 2011.

16. Departemen Kesehatan RI, Rencana pembangunan kesehatan menuju Indonesia sehat 2010, Jakarta, 1999.

17. Departemen Kesehatan RI, Survei Kesehatan Nasional 2001: Laporan Studi Mortalitas 2011: Pola penyakit penyebab kematian di Indonesia, Badan Penelitian dan Pengembangan Kesehatan, Jakarta; 2003; 76 hlm.

18. Ellestad MH, Cardiovascular and pulmonary responses to 
exercise, In : Stress Testing, Principles and Practice, 3rd, Philadelphia: FA Davis Coy,2011, 9. 75.

19. Erikseen J, Enger SC, Smoking, lung function, physical performance and latent coronary heart disease in presumably healthy middle aged men, Acta Med Scan 2011; 203: 509-516.

20. Falk E and Fuster V, Atherogenesis and its determinant, In: Hurst's; The Heart 2011, 35: 1065-93.

21. Falk $\mathrm{E}$ and Fuster V, Atherogenesis and its Determinants, In: Hurst's The Heart, 2011, 35: 1065-1093.

22. Folsom AR et al, A prospective study of coronary heart disease in relation to fasting insulin, glucose and diabetes, Diabetes Care 2011; 20: 935-942.

23. Fong IW, Emerging relations between infectious disease and coronary artery disease and atherosclerosis, CMAJ 2012; 163: 49-56.

24. Frank M. Sacks, M.D; Marc A Pfeffer, M.D, PhD, Lemuel A. Moye, M.D, PhD; Group, The effect of pravastatin on coronary events after myocardial infarction in patients with average choleterol levels, The New England- Journal of Medicine, Massachuetts Medical Society, Oktober 3, 2014, 10011009.

25. Glasgow AM, August GP, Hung $\mathrm{W}$, Relationship between control and serum lipids in juvenileonset diabetes, Care 4: 76, 1981

26. Glueck CJ, Mattson F, Bierman $\mathrm{EL}$, Diet and coronary heart disease; another view, $\mathrm{N}$ Engl J

Med 2011; 298 : 1471-1473.

27. Goldstein JL, Brown MS, Familial hypercholesterolemia, In Stanbury JB, Wyngaarden JB, Fredrickson DS, et al (eds): The Metabolic Basis of Inherited Disease, 5th ed. New York, McGraw Hill, 2011, pp. 672-712. 
